J. KUEThE, * Y.-L. ZhONG,* N. YASUDA,* G. BEUTNER, K. LinN, M. KiM, B. MARCUNE,

S. D. DREHER, G. HUMPHREY, T. PEI (MERCK RESEARCH LABORATORIES, RAHWAY, USA) Development of a Practical, Asymmetric Synthesis of the Hepatitis C Virus Protease Inhibitor MK-5172

Org. Lett. 2013, 15, 4174-4177.

\title{
Synthesis of MK-5172
}<smiles>COc1ccc2nc(Cl)c(Cl)nc2c1</smiles>

A

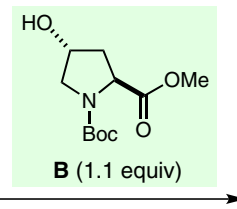

DBU ( 1,5 equiv) DMAc, $50^{\circ} \mathrm{C}, 20-30 \mathrm{~h}$ $71 \%(175 \mathrm{mmol}$ scale $)$<smiles>COc1ccc2nc(Cl)c(O)nc2c1</smiles><smiles>C=C(OC)[C@H]1C[C@H](C)CN1C</smiles>
Boc O C $\mathrm{mp} 98.5^{\circ} \mathrm{C}$

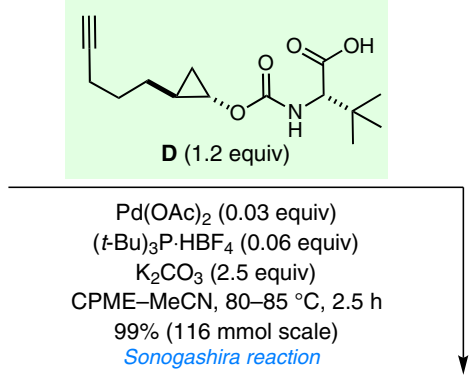<smiles>COC(=O)C1C[C@@H](Oc2nc3cc(OC)ccc3nc2CCCCCCC2CC2)N(C(=O)[C@H](NC(=O)OC2CC2)C(C)(C)C)C1</smiles>

mp $230{ }^{\circ} \mathrm{C}$

$\mathrm{LiOH}$ (5 equiv)

THF- $\mathrm{H}_{2} \mathrm{O}, 40^{\circ} \mathrm{C}, 1 \mathrm{~h}$

$98 \%$ (62 mmol scale)

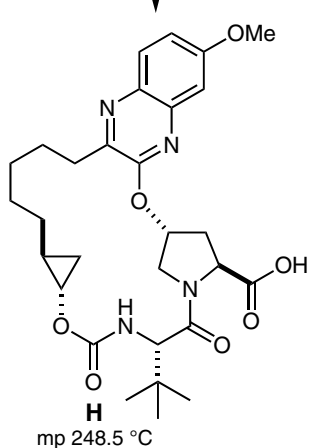<smiles>COC(=O)C1C[C@@H](OC2=NC(C)=NCC2CCCCCC2C[C@H]2OC(=O)N[C@H](C(=O)O)C(C)(C)C)N=C1CCCCC(=O)O[Na]</smiles>

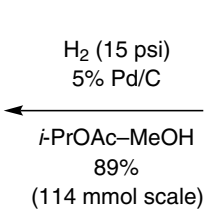<smiles>COC(=O)C1C[C@H](Oc2nc3cc(OC)ccc3nc2C#CCCCC2CC2OC(=O)N[C@H](C(=O)O)C(C)(C)C)CN1C(=O)c1ccccc1</smiles>

Gategory

Synthesis of Natural Products and

Potential Drugs

\section{Key words}

\section{MK-5172}

hepatitis $C$ virus protease inhibitor

macrolactamization

Sonogashira

reaction
Significance: MK-5172 is a hepatitis C virus protease inhibitor. Key steps in the synthesis depicted are (1) the regioselective $S_{N} A r$ reaction of dichloroquinoxaline $\mathbf{A}$ with prolinol derivative $\mathbf{B}$ and (2) construction of the 18-membered macrocycle using a macrolactamization $(\mathbf{F} \rightarrow \mathbf{G})$.

SYNFACTS Contributors: Philip Kocienski

Synfacts 2013, 9(11), 1145 Published online: 18.10.2013

Dol: 10.1055/s-0033-1339864; Reg-No.: K06313SF
Comment: The medicinal chemistry route to MK-5172 is based on a ring-closing metathesis strategy (S. Harper et al. ACS Med. Chem. Lett. 2012, 3, 332). The best regioselectivity (20:1) and minimization of double substitution in the $S_{N} A r$ reaction of $\mathbf{A}$ with $\mathbf{B}$ was achieved using 1,8-diazabicyclo[5.4.0]undec-7-ene (DBU) as the base in polar solvents such as DMSO, NMP, or DMAc. 